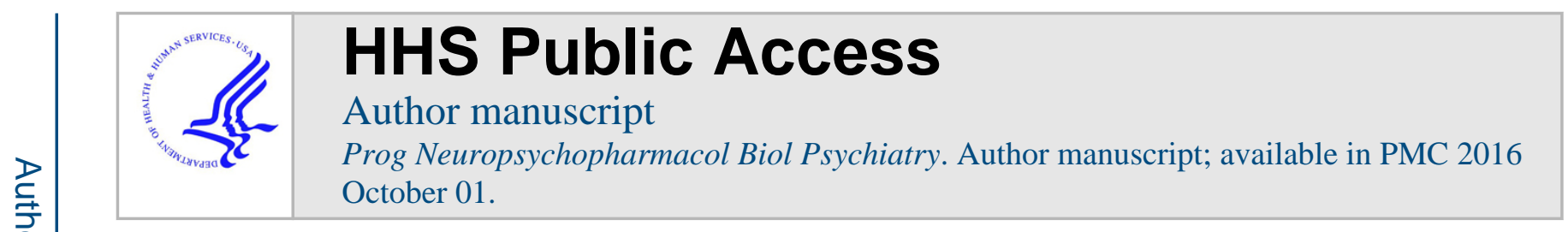

Published in final edited form as:

Prog Neuropsychopharmacol Biol Psychiatry. 2015 October 1; 62: 51-60. doi:10.1016/j.pnpbp. 2015.01.001.

\title{
Kappa Opioid Receptor Signaling In the Brain: Circuitry and Implications for Treatment
}

\author{
Nicole A. Crowley ${ }^{1,2}$ and Thomas L. Kash ${ }^{2,3}$ \\ ${ }^{1}$ Neurobiology Curriculum, University of North Carolina at Chapel Hill, Chapel Hill, NC 27599, \\ USA \\ ${ }^{2}$ Bowles Center for Alcohol Studies, University of North Carolina at Chapel Hill, Chapel Hill, NC \\ 27599, USA \\ ${ }^{3}$ Department of Pharmacology, University of North Carolina at Chapel Hill, Chapel Hill, NC 27599, \\ USA
}

\section{Abstract}

Kappa opioid receptors (KORs) in the central nervous system have been known to be important regulators of a variety of psychiatry illnesses, including anxiety and addiction, but their precise involvement in these behaviors is complex and has yet to be fully elucidated. Here, we briefly review the pharmacology of KORs in the brain, including KOR's involvement in anxiety, depression, and alcohol addiction. We also review the known neuronal circuitry impacted by KOR signaling, and interactions with corticotrophin-releasing factor (CRF), another key peptide in anxiety-related illnesses, as well as the role of glucocorticoids. We suggest that KORs are a promising therapeutic target for a host of neuropsychiatric conditions.

\section{Abstract}

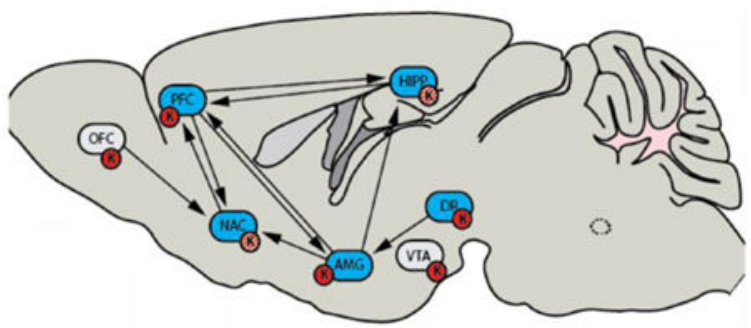

\section{Keywords}

KOR; dynorphin; stress; anxiety; addiction; circuitry

(C) 2015 Elsevier Inc. All rights reserved.

Publisher's Disclaimer: This is a PDF file of an unedited manuscript that has been accepted for publication. As a service to our customers we are providing this early version of the manuscript. The manuscript will undergo copyediting, typesetting, and review of the resulting proof before it is published in its final citable form. Please note that during the production process errors may be discovered which could affect the content, and all legal disclaimers that apply to the journal pertain. 


\section{Background: KORs in the Central Nervous System}

Kappa opioid receptors (KORs) and their endogenous ligand, the peptide dynorphin (Chavkin \& Goldstein 1981a, Chavkin \& Goldstein 1981b, Chavkin et al 1982) are at the forefront of potential therapeutic targets for a range of health issues, including anxiety, depression, and drug addiction (Bruchas et al 2010). Here, we outline current neurobiological research of KORs, focusing on the discrete circuit elements that are regulated by KOR signaling and their role in behavior.

\section{Pharmacology}

Kappa opioid receptors are seven transmembrane g-protein coupled receptors, coupled to Gai/o, and are known to utilize a variety of signaling cascades (reviewed in detail, (Bruchas \& Chavkin 2010a)). KORs signal through both Ga and G $\beta \gamma$ subunits, and then activate a host of downstream signaling molecules, thereby activating g-protein gated inwardly rectifying potassium channels (GIRKs), reducing calcium currents, and decreasing cyclic AMP. KORs have been shown to activate both MEK/ERK (Belcheva et al 2005, Hahn et al 2010, Kivell et al 2014a, Li et al 2012, McLennan et al 2008, Potter et al 2011, Yoshizawa et al 2011) (although some groups do not see significant MEK/ERK activation following KOR activation, see (Asensio et al 2006)) and MAPK signaling cascades, and in particular, p38 (Bruchas et al 2006, Bruchas et al 2011, Hahn et al 2010, Yoshizawa et al 2011). This KOR interaction with $\mathrm{p} 38$ is thought to be mediated by arrestin signaling; co-expression with the dominant-mutant of $\beta$-arrestin prevents human KOR internalization in $\mathrm{CHO}$ cells ( $\mathrm{Li}$ et al 1999). The interaction between $\mathrm{p} 38$ and arrestin may mediate the dysorphia-like side effects of KOR agonists (Bruchas et al 2007), possibly through a reduction in biogenic amine levels (Chefer et al 2005, Spanagel et al 1994) such as serotonin, as shown in Bruchas et al. The ability of KORs to signal through different GPCR signaling cascades may prove useful in creating biased agonists at the KOR, allowing for therapeutic treatments for pain or neuropsychiatric illnesses without the unwanted side effects, such as dysphoria and psychomemetic effects observed in humans (Pfeiffer et al 1986). Interestingly, KORs can utilize different signaling cascades in a single brain region (Hjelmstad \& Fields 2003). Notably, Hjelmstad \& Fields demonstrated that while KOR activation inhibits GABA release via a calcium dependent mechanism, it's inhibition of glutamate is calciumindependent. Other groups have similarly demonstrated KOR-mediated inhibition of GABA (Li et al 2012), but more in-depth assessments of biased KOR signaling in a single brain region have not been conducted. Potent long acting inhibitors of KOR include norBNI (Endoh et al 1992) and JDTic (Bruchas \& Chavkin 2010b). More recently, short acting antagonists such as LY2456302, and the tracer 11C-LY2795050 developed by Eli Lilly and Company have recently emerged (Lowe et al 2014, Zheng et al 2013). As KORs may utilize different signaling cascades, understanding this divergent pharmacological mechanisms will not only lead to greater understanding of the role KORs play in an assortment of behaviors and conditions, it will also allow for greater tailoring of pharmacological treatments. 


\section{Behavior \\ Depression}

The forced swim test (FST) is a classic screen for depressive phenotypes, and has been used since the 1970s as a way to screen for novel antidepressive drugs (Porsolt et al 1977).

Porsolt et al. first described the FST as a measurement of behavioral despair, wherein immobility indicates the animal is no longer attempting to escape the experimental condition; antidepressants typically reverse this behavior (Castagné et al 2001) (however, it should be noted that though the FST is effective as a screen for anti-depressants, it was not originally intended as a measurement of an actual depressive phenotype in the rodent). KOR antagonists produce antidepressant like effects in the FST, as measured by a decrease in immobile behavior (Reindl et al 2008). A variety of studies have shown that administration of the KOR antagonist norBNI leads to decreased immobility in the FST (Carr et al 2009, Mague et al 2003). norBNI-induced decreases in immobility and increases in swimming are observed in Wistar Kyoto rats, but not Sprague Dawleys, highlighting important strain differences (Carr et al 2010). This effect was also seen when Carr et al. administered norBNI directly into the piriform cortex. The KOR antagonist DIPPA prevented the adenosinemediated decrease in immobility time in the FST, highlighting how KORs' effect on depressive-like behaviors may involve the moderation of other neurotransmitter systems (Kaster et al 2007). Therefore, as the KOR system seems to produce a robust phenotype in the FST, this behavioral test may function as a useful screen for future KOR antagonist compound development.

In addition to it's effects on the FST model of depression, KORs are also involved in depressive like states following drug withdrawal. Work from Chartoff et al. has demonstrated that though norBNI alone had no effect on latency to immobility in the FST, norBNI was able to block the cocaine-withdrawal induced decrease in time to immobility (Chartoff et al 2012). Like norBNI, JDTic has been shown to decrease immobility in the FST, and JDTic also decreased stress-induced reinstatement of cocaine responding (Beardsley et al 2005). In other behavioral assays related to depression, site specific infusion of the KOR antagonist norBNI in to either the hippocampus and nucleus accumbens was able to prevent the depressive phenotype seen in a learned helplessness paradigm (Shirayama et al 2004). Consistent with these results, KOR agonists also increase intracranial self-stimulation (ICSS) thresholds, indicating a potential depressive-like phenotype (Todtenkopf et al 2004).

\section{Anxiety}

Much of the animal literature has focused on KOR-modulation of anxiety related behaviors. A common test for rodent anxiety, the elevated plus maze (EPM), involves letting the rodent explore an apparatus with both closed arms and open exposed arms, with more time spent exploring the open arms being indicative of an anxiolytic phenotype (Pellow \& File 1986). Knoll et al. showed that administration of the KOR antagonist norBNI resulted in an anxiolytic phenotype in the EPM (Knoll et al 2011). KOR antagonists can also reverse the anxiogenic effects of stress in the EPM (Peters et al 2011), and similarly, KOR antagonists can reverse the anxiogenic effects of a KOR agonist (Valdez \& Harshberger 2012). These 
experiments would point to an anxiogenic effect of KOR agonists, and an anxiolytic effect of KOR antagonists. However, some contradictory literature has emerged: administration of the KOR agonist Salvinorin-A increases both open arm time and entries into the open arm of the EPM (Braida et al 2009). In addition, the KOR agonist U50,4888 can produce anxiolytic effects in the EPM at low doses (10-100ug/kg) (Privette \& Terrian 1995). These discrepancies may be driven by two important points: first, in the Braida et al., study, Salvinorin-A was used. Salvinorin-A has been shown to utilize the ERK1/2 signaling cascade (Kivell et al 2014b), and this biased ligand may produce differential behavioral effects as compared to those of other KOR agonists (this hypothesis of differential effects by some KOR agonists is supported by work demonstrating that ICV administration of low, but not high, doses of Salvinorin produces a robust conditioned place preference (Braida et al 2008)). Similarly, the global anxiogenic effect of KOR agonists may be dose dependent; the conditioned place preference seen by Braida et al., as well as the anxiolytic effect in the EPM seen by Privette \& Terrian, were seen at lower doses of KOR agonists that typically used. This may indicate that KOR agonists do have the potential to be used for therapeutic purposes, but much more research is needed.

Taken together, the literature on KORs and both depression and anxiety provides a mixed and muddled picture at best. Future experiments will need to address the nuances of behavioral effects (such as comparing multiple KOR agonists, and importantly, detailed dose response curves) in order to thoroughly understand the relationship between the dynoprhin/KOR signaling system and depression and anxiety. In addition, circuit and sitespecific manipulations, discussed below, provide some clarity as to the convoluted effect seen with systemic administration of KOR agonists. This provides key important information as to how KOR modulation can be used to shift anxiety-related behaviors: both low doses of KOR agonists, as well as KOR antagonists, may prove to be effective.

\section{Addiction}

KORs have been shown to be involved in the consumption, withdrawal, and escalation of a variety of drugs of abuse, such as alcohol (Zhou et al 2013) heroin (Schlosburg et al 2013, Sedki et al 2014) and cocaine (Al-Hasani et al 2013, Trifilieff \& Martinez 2013b). Despite an abundance of literature showing KORs to be a promising therapeutic target for the treatment of drug addiction (Hasebe et al 2004, Wee \& Koob 2010) few drugs impacting the KOR system have been taken to the level of human clinical trials. The KOR antagonist JDTic did reach stage 1 clinical trials for the treatment of cocaine dependence, but the research was terminated due to adverse effects (RTI-International May 9, 2012). The antagonist LY2456302 has upcoming phase 1 and phase 2 clinical trials for treatment resistant depression, anxiety disorders, and has completed phase 1 clinical trials for alcohol dependence (Massachusetts General Hospital July 30, 2013). The existing animal literature on KORs and addiction, discussed below, should encourage further clinical investigations.

Work on the KOR system and cocaine has shown that activation of KORs can reduce cocaine self-administration (Glick et al 1995), and the utility of mixed mu/kappa opioid receptor agonists have been shown for the treatment of cocaine dependence (Bidlack 2014). Administration of both a KOR agonist and cocaine blocks sensitization to the conditioned 
rewarding properties of cocaine using a conditioned place preference model (Shippenberg et al 1996). Freeman and colleagues used experimental manipulations in non-human primates to support the hypothesis that this suppression of self-administration and rewarding properties of cocaine may be due to the ability of KOR agonists to punish responding for cocaine (Freeman et al 2014). In these experiments, monkeys decreased operant responding for either cocaine or remifentanil when paired with the KOR agonist Salvinorin A, highlighting the potential role of the KOR system to curtail drug self-administration. The hypothesized mechanism for KOR-induced changes in cocaine administration and dependence is fairly well established, as KORs are present on dopaminergic terminals and can inhibit dopamine release (Trifilieff \& Martinez 2013a). However, Ehrich, Phillips, and Chavkin (2014) found that KOR activation can potentiate cocaine-induced increases in evoked dopamine release, depending on the timing of KOR activation and cocaine administration (Ehrich \& Phillips 2014). This study emphasizes that while KORs may be a promising target for drug addiction, for cocaine in particular and likely for other drugs as well, timing of the intervention may be crucial. If KOR activation can both increase and decrease drug self-administration based on timing, it is unlikely to be useful for treating addiction (to those particular drugs) in the real world.

KORs have also been implicated in morphine abuse, by interacting with morphine's ability to potentiate dopamine release in the nucleus accumbens via its actions at the mu opioid receptor (MOR) in the ventral tegmental area (Vander Weele et al 2014). Supporting this hypothesis, MOR and KOR agonists have opposing effects on dopamine release, with the former potentiating and the latter attenuating dopamine release (Di Chiara \& Imperato 1988). Administration of the KOR agonist U50,488 is capable of blocking morphine conditioned place preference (Funada et al 1993). Dynorphin-A levels are altered during the development of morphine dependence, with levels increased in the hippocampus and hypothalamus (Wan et al 1998). Interestingly, strains of mice with higher pro-dynorphin expression appear to be morphine insensitive, hinting at a mechanism by which the dynorphin/KOR system may protect against the abuse-potential of drugs activating the MOR system (Gieryk et al 2010). Taken together, the existing literature on KOR/MOR interactions suggests the dynorphin system may be a promising target for intervening in MOR-related drugs of abuse, such as morphine.

Research regarding KORs and alcohol addiction has become more prevalent in the last decade, with a greater emphasis being placed on the molecular role of the dynorphin system (Faisal et al 2014) and its potential therapeutic role in alcoholism (Heilig \& Schank 2014, Nutt 2014, Walker et al 2012). Leeman et al. discussed in depth how various animal models can appropriately recapitulate human studies, and importantly, the authors highlight the role alcohol consumption and abstinence (as well as heavy drinking) can play in informing the human literature (Leeman et al 2010). In the human population, genetic variants in the KOR gene OPRK1 modulate alcohol consumption (Li \& Zhang 2013, Wang et al 2014) (though note that this effect is not replicated in all populations; see (Cupic et al 2013)). KOR antagonists can prevent alcohol self-administration in alcohol preferring rat lines (Cashman \& Azar 2014). Interestingly, administration of KOR agonists can also attenuate responding for alcohol in an operant paradigm (Henderson-Redmond \& Czachowski 2014). KORs are required for alcohol-induced increases in brain-derived neurotrophic factor (BDNF) in the 
striatum (Logrip et al 2008). Targeting KORs with U50,488 blocks the rewarding effects of ethanol during conditioning, importantly, this was seen with sub-anxiogenic doses of the KOR agonist (Logrip et al 2009). Mice lacking KORs show decreased alcohol selfadministration (Kovacs et al 2005), and alcohol self-administration leads to an upregulation of dynorphin in the central amygdala, a region of the extended amygdala (D'Addario et al 2013). Mice lacking dynorphin show increased alcohol preference; however, in contrast to control littermates, they do not show increased alcohol consumption following a mild stressor (Racz et al 2013). Therefore, it seems that both antagonist and agonists of KORs may play a promising therapeutic role in treating alcohol addiction, but much like the cocaine, depression, and anxiety literature, the timing and nature of intervention and state of the individual may be crucial.

Alcohol consumption, however, is only one part of the spectrum of alcohol addiction. Reinstatement models (as reviewed in detail in (Le \& Shaham 2002) allow for critical assessment of another component of addiction, relapse. Though it can be difficult to model alcohol relapse in a rodent (as noted in Leeman et al. 2009), reinstatement provides relevant information on this topic. In addition to effects on alcohol consumption, KORs appear to play an important role in withdrawal from alcohol and further alcohol seeking. Administration of the KOR agonist U50,488 reinstated alcohol seeking in a norBNIdependent manner (Funk et al 2014). In addition, Funk and colleagues found that norBNI pretreatment 2 hours before the session blocked yohimbine-induced reinstatement of alcohol seeking, further elucidating the KOR/stress interactions in alcohol seeking behaviors. Schank and colleagues similarly demonstrated that the KOR antagonist JDTic attenuates both alcohol seeking behaviors and withdrawal (Schank et al 2012). Berger et al. has demonstrated that norBNI dose-dependently decreased post-alcohol ultrasonic vocalizations, an indicator of negative affective state; in addition, norBNI altered cue induced alcohol consumption. (Berger et al 2013). However, Morales and colleagues demonstrated that the KOR antagonist norBNI increased alcohol self-administration in male rats, while decreasing self-administration in females, highlighting key differences in KOR-mediated alcohol phenotypes (Morales et al 2014).

This relationship between alcohol and KORs may be bi-directional: mice exposed to alcohol prenatally had altered KOR systems, and displayed an appetitive response to KORs (Nizhnikov et al 2014). Interestingly, prenatal exposure to alcohol increases ethanol intake later, and this effect is partially blocked by KOR antagonists (Diaz-Cenzano et al 2014). And, despite the abundance of this behavioral evidence, little has been done to investigate the mechanism of interaction between alcohol and KORs, and most of the existing literature focuses in the central amygdala (Gilpin et al 2014, Kang-Park et al 2013, Kissler et al 2014).

\section{Paradoxical Effects}

The KOR system has been shown to be involved in numerous psychiatric-disease related behaviors, including depression, stress, and addiction. Important studies using modern genetic approaches have highlighted the multiple ways that KORs effect behavior, and paradoxical effects have emerged when manipulating the dynorphin system. For example, researchers found that when dynorphin was genetically deleted globally, mice showed 
enhanced cue-dependent fear conditioning (Bilkei-Gorzo et al 2012) as well as enhanced social partner recognition (Bilkei-Gorzo et al 2014). In addition, these dynorphin knock out (KO) mice showed decrease c-fos immunoreactivity in key limbic brain regions. In another paper, the authors demonstrated that dynorphin $\mathrm{KO}$ mice show subtle alterations in anxiety, most notably increased startle amplitude in the startle response test (Bilkei-Gorzo et al 2008). These results would conclude that dynorphin KO mice show increased fear and anxiety, and increased pro-social behaviors. In contrast to this finding, administration of norBNI or JDTic increases open arm time in the elevated plus maze (EPM), with no effect on general locomotor behavior in rats (Knoll et al 2007), thought to be representative of an anxiolytic phenotype (other examples of behavioral studies consistent with Knoll et al. are outlined below). Though this work by Bilkei-Gorzo et al. may at first seem contradictory to the dogmatic perspective of dynoprhin as a stress and anxiety peptide, it importantly highlights the mixed role that dynorphin and KORs may play throughout the brain. While KOR activation in regions such as the hippocampus may have protective effects, activation in regions such as those involved in anxiety-related behaviors (amygdala, prefrontal cortex) may have negative effects, as discussed below. In addition, key differences between the work of the Bilkei-Gorzo et al. and Knoll et al. studies include timepoint of manipulation of the KOR system; importantly, those where dynorphin is knocked out from birth, and compensatory mechanisms may come on board, versus those with site-specific dynorphin manipulations. The work from the Zimmer group may highlight that when KORs are globally excised from birth, other compensatory mechanisms may regulate anxiety and fear related behaviors. Equally important, the work by Bilkei-Gorzo et al. (2008, 2012, 2014) was conducted in dynorphin $\mathrm{KO}$ mice maintained on a $\mathrm{C} 57 \mathrm{Bl} / 6 \mathrm{~J}$ background; Knoll et al. used Sprague-Dawley rats, highlighting what may be important species differences in mammalian models of anxiety related behaviors. In addition, an important study by Chefer and Shippenberg provided some clarify to the perplexing effects sometimes seen with dynorphin KO mice (Chefer \& Shippenberg 2006). The authors find that developmental compensations following dynorphin KO may lead to changes in the endogenous dopamine system; specifically, dynorphin KO mice shown decreased extracellular dopamine in the nucleus accumbens, resulting in a decreased responsiveness to cocaine. Thus, global manipulation of the KOR/dynorphin system may prove to be problematic as a tool to develop treatments for disorders related to the mesolimbic dopamine system, such as anxiety, depression, and addiction, and must be pursued with caution. It may be more fruitful to use pharmacological versus genetic manipulations of the dynorphin KOR system when developing therapeutic lines of research.

\section{Circuitry}

Key brain regions have emerged as major players in the actions of KORs - notably, the dorsal raphe (DR) nucleus, the ventral tegmental area (VTA), the nucleus accumbens (NAC), the prefrontal cortex (PFC), the amygdala and extended amygdala, and the hippocampus (HIPP). Novel technological approaches, including genetically modified mice, optogenetics, and other site-specific manipulations, have allowed for a more in-depth analysis of these crucial brain regions, further informing potential therapeutic targets. Importantly, this approach has allowed researchers to parse apart discrepancies seen with 
classic behavioral pharmacology approaches, and provide a more detailed picture into the roles of the KOR dynoprhin system.

\section{Dorsal Raphe Nucleus}

The DR contains the majority of the brain's serotonergic neurons (Lowery-Gionta et al 2014), and is involved in established KOR mediated behaviors, such as dysphoria (Lemos et al 2012, Maier \& Watkins 2005), and alcohol addiction (Tomkins et al 1994). Site-specific administration of the KOR agonist U50,488 into the DR decreased extracellular serotonin by approximately $30 \%$ (Tao \& Auerbach 2005). Behaviorally, KORs in the DR have been shown to be necessary for stress related behaviors. In recent years, work from Chavkin and colleagues has thoroughly investigated KORs in the DR and their relationship to stress. They demonstrated (Land et al 2009) that administration of the KOR antagonist norBNI into the DR blocked not only aversive effects of the KOR agonist U50,488, but also blocked stress-induced reinstatement of CPP. In addition, Land and colleagues further elucidated that this phenotype is dependent on DR projections to the nucleus accumbens. In follow-up studies, they (Bruchas et al 2011) demonstrated that stress regulates the serotonin transporter via a p38 MAPK dependent mechanism, and that deletion of p38 from serotonin neurons in the DR prevents the development of stress-induced avoidance behavior, as well as a host of other stress-related phenotypes; this $\mathrm{p} 38$ mediated translocation of the SERT appears to be KOR-mediated.

Further enhancing our understanding of KORs in the DR, Lemos et al. (2012) also investigated KOR effects using slice electrophysiology. KOR activation in the DR produces an inhibition of evoked glutamatergic transmission onto DR serotonergic neurons, as well a decrease in miniature excitatory post synaptic current frequency (Lemos et al 2012). Interestingly, Lemos and colleagues did not see changes in GABAergic transmission (evoked and miniature), indicating KOR regulation of the serotonergic system may be largely through inhibition of excitatory inputs onto serotonin neurons. However, no published work to date has looked at KOR modulation onto other DR neuron subtypes, such as the dopaminergic population; other neurons may also be inhibited by KOR, effectively shutting down DR communication. In addition, KORs increase post-synaptic G-proteingated inwardly rectifying potassium channels (GIRK) currents in the DR; this KORactivated GIRK is reduced following exposure to a two day forced swim stress procedure while the effects of KORs on glutamate transmission remain unaltered following stress. This work was complementary to previous published work (Pinnock 1992) that demonstrated KOR activation inhibited excitatory post-synaptic potentials (EPSPs) in the DR. However, Pinnock did not see any effects on membrane potential with the KOR agonist CI-977. In contrast to the GIRK-mediated effects of U69593 shown by Lemos et al. Pinnock did not have access to cell-type specific recording techniques; in addition, Pinnock's study was conducted in rats while Lemos et al.'s was conducted in mice, possibly explaining the differences in the two publications.

\section{Ventral Tegmental Area}

Kappa opioid receptors have been studied in the VTA for their role in the inhibitory modulation of dopamingeric neurons (Shippenberg et al 1993), both on the cell bodies

Prog Neuropsychopharmacol Biol Psychiatry. Author manuscript; available in PMC 2016 October 01. 
within the VTA and downstream dopamine targets, such as the medial prefrontal cortex (Tejeda et al 2013). KORs have been demonstrated to co-express with the dopamine transporter (Svingos et al 2001), and KORs located on dopaminergic neurons are necessary for conditioned place aversion (Chefer et al 2013). Chefer et al. demonstrated that when KORs are selectively deleted from dopamine neurons, mice do not display conditioned place aversion to a systemic KOR agonist, as their control counterparts do. This work is consistent with previously published studies demonstrated that microinjection of a KOR agonist directly into the VTA produce conditioned place aversion (Bals-Kubik et al 1993), and is consistent with slice electrophysiology experiments demonstrating that postsynaptic KORs directly inhibit dopamine neurons (Margolis et al 2003). There are likely KORs located on other neurons within the VTA as well, such as on the gabaergic populations synapsing onto dopamine neurons (Graziane et al 2013). Graziane et al. demonstrated that an acute stressor blocks GABAergic long-term potentiation (LTP) in the VTA, but this LTP is rescued when a KOR antagonist is administered prior to exposure to the stressor. In addition, slice experiments have demonstrated that KORs inhibit glutamate transmission onto VTA neurons (Margolis et al 2005) (notably, a previous study did not see KOR inhibition of glutamate transmission in the VTA (Manzoni \& Williams 1999); however, as noted in the Margolis et al., paper, Manzoni \& Williams did see a high degree of variability in their KOR agonists effects, and an inhibition may have emerged if parsed apart by cell type characteristics. For example, (Margolis et al 2006) demonstrate that KORs selectively inhibit PFC projecting dopamine neurons in the VTA, and to the amygdala (Margolis et al 2008), but not those that project to the NAC. Importantly, interactions with other neuropeptides have recently been discovered; dynorphin projections to the VTA also coexpress with orexin, and orexin can facilitate reward in ICSS by blocking KOR-mediated effects (Muschamp et al 2014). Taken together, work on KORs in the VTA shows a surprisingly consistent and concise effect on dopamine neurons and local circuitry, as well as conditioned place aversion and addiction, but much work is left to be done in order to understand how this local circuit interacts with inputs to the VTA. Importantly, KORs also modulate the major downstream target of the VTA, the NAC, discussed below.

\section{Nucleus Accumbens}

Dynorphin and KORs are known to be important regulators of NAC circuitry; KOR activation inhibits glutamate transmission in the NAC, and is abolished during cocaine withdrawal (Mu et al 2011). Using microdialysis, Spanagel et al. (Spanagel et al 1992) demonstrated that activation of KORs by the KOR agonist U69593 inhibited dopamine release (and complementary, the antagonist norBNI enhanced dopamine release). Interestingly, the main dopaminergic projection to the NAC, arising from the ventral tegmental area (VTA) is also inhibited by KOR activation (Margolis et al 2003). The Berridge lab (Castro \& Berridge 2014) recently published a comprehensive study of opioids in the NAC: activation of KORs (as well as the $\mathrm{u}$ - and delta- opioid receptors) in the NAC "hotspot", the rostrodorsal quadrant of the medial shell, was found to positively regulate "liking" and "wanting" responses. Castro \& Berridge similarly discovered a "coldspot" for hedonic responses in the NAC. This work very importantly, and interestingly, indicates that not just KORs, but the location of KORs, may be integral to their much-researched regulation of stress and anxiety related behaviors. 
Stress increased prodynorphin mRNA in the NAC, possibly through a CREB dependent mechanism (Chartoff et al 2009). Following resident intruder stress, dynorphin mRNA in the NAC dorsal and medial shell is increased, which, in conjunction with other experiments, the authors hypothesize promotes maladaptive behavioral responses following stress (Berube et al 2013). Similarly, dynorphin mRNA in the NAC was altered following protracted withdrawal from repeated immobilization stress (Lucas et al 2011). Following a forced swim stress procedure, Bruchas et al. found increased phosphorylation of ERK1/2 in the NAC, which was blocked by the KOR antagonist norBNI and absent in KOR knockout mice (Bruchas et al 2008). Stress similarly causes a dynorphin-dependent increase in KOR activation in the NAC, as well as the basolateral amygdala, HIPP, DR, and basolateral amygdala, all discussed in detail in other sections of this review (Land et al 2008).

Much of the work on KORs in the NAC has been done in the context of drug addiction, particularly cocaine, allowing greater clarity as to how KORs modulate the reward system. The Shippenberg group (Gehrke et al 2008) demonstrated that KORs enhance cocaineevoked dopamine overflow. Similarly, the Chavkin lab (Ehrich \& Phillips 2014) showed that KOR activation can enhance cocaine-induced increases in dopamine release. Erich and colleagues explain the time dependence of KOR agonist/cocaine administration: when KORs are activated in close proximity to cocaine administration, a dysphoric effect occurs, as the KOR activation has blocked cocaine's rewarding properties; however, when they are activated at greater time differences (over 20 minutes apart), the KOR activation leads to a greater enhancement of the cocaine's effects, possibly to overcome the dysphoric effect of the KOR activation. Previously, the Chavkin lab (McLaughlin et al 2006) similarly demonstrated that KORs effects on cocaine conditioned place preference (CPP) were time dependent; in addition, forced swim stress induced cocaine CPP was unaltered in KOR(-/-) mice as compared to WT controls, and the effect in WTs was blocked by the KOR antagonist norBNI (also see (McLaughlin et al 2003)). These findings provide important insight into the time dependents of KOR-mediate stressors and the development of drug addiction; blocking KORs during stress may help prevent the development of further cocaine use.

Modulation of KORs has potential therapeutic benefits for other drugs of abuse as well. The Koob lab (Schlosburg et al 2013) found that pretreatment with norBNI prevented escalation in heroin intake seen in a long-access paradigm in rats, while also reducing anxiety-like behavior seen with withdrawal. This decrease in heroin self-administration was also seen when norBNI was administered site-specifically into the NAC shell (however, administration into the NAC core increased heroin self-administration, but not the escalation of intake).

\section{Prefrontal Cortex}

Though much work has been done looking at the role of KORs the main nuclei of the mesolimbic dopamine system (the NAC and VTA), other downstream dopaminergic projections, such as the PFC. KORs are known to be located presynaptically in the PFC (Svingos \& Colago 2002), and recently Tejeda and colleagues looked at this putative pathway in-depth. Tejeda and colleagues (Tejeda et al 2013) demonstrated that systemic 
administration of the KOR agonist U50,488 decreased extracellular dopamine levels in the medial PFC (without altering reuptake). Interestingly, they also demonstrated KORs presynaptically inhibit glutamate release onto pyramidal neurons. This provides a putative circuit for Bals-Kubik et al.'s (Bals-Kubik et al 1993) findings that administration of a KOR agonist directly into the PFC causes a conditioned place aversion, possibly through inhibition of dopaminergic and glutamateric drive onto PFC neurons.

\section{The Amygdala and Extended Amygdala}

The basolateral amygdala (BLA) and its downstream nuclei, the central nucleus of the amygdala (CeA) and bed nucleus of the stria terminalis (BNST) are enriched with both KOR and dynorphin, and thus are of increasing interest. The Carlezon group (Knoll et al 2011) demonstrated that fear conditioning upregulated KOR mRNA in the BLA (but not CeA), and that site-specific administration of the KOR antagonist JDTic decreased conditioned fear (effective fear conditioning was associated with a reduction of KOR mRNA in the BLA). Interestingly, administration of JDTic to the BLA (but not CeA) produced an anxiolytic phenotype in the elevated plus maze (EPM), a common anxiety test. The Chavkin Lab (Bruchas et al 2009) previously published a similar anxiolytic effect of BLA KORs; they found site specific administration of norBNI blocked a forced swim- or CRF- induced stress phenotype in the EPM. It has also been found that activation of KORs by U50,488 decreased synaptic local field potentials, as well as blocked high-frequency-induced long term potentiation (Huge et al 2009). However, the mechanism of KORs in the BLA has not been investigated further.

Dynorphin containing neurons have been demonstrated in the CeA, where they occasionally co-express with CRF (Marchant et al 2007). Following alcohol intake, sardinian alcohol preferring (SP) rats show increased preprodynorphin levels in the CeA as compared to both alcohol naïve- SP rats and alcohol naïve- non preferring rats (Zhou et al 2013). Work by Koob et al. and Roberto et al. has focused extensively on characterizing KORs here, and their interactions with alcohol. Gilpin and colleagues (Gilpin et al 2014) demonstrated that KOR activation by dynorphin decreased GABAergic transmission in the $\mathrm{CeA}$, while the antagonist norBNI enhanced GABAergic transmission, indicating the presense of a tonic dynorphin tone. In addition, Gilpin et al. showed that KOR activation partially blocked the effects of ethanol at these synapses. This effect was complementary to results published the previous year (Kang-Park et al 2013) demonstrated that KOR activation decreased GABAergic transmission in the CeA, and also demonstrating tonic activation of KORs, through a presynaptic mechanism. Interestingly, previous studies have shown that KOR activation decreased GABAergic transmission in naïve rats, consistent with Gilpin et al., while it increased GABAergic transmission in rats exposed to a long-access cocaine paradigm (Kallupi et al 2013). They also found that site-specific administration of norBNI blocked cocaine-induced locomotor sensitization, as well as decreased withdrawal related behaviors. KORs in the CeA may prove to be an interesting target for the manipulation and treatment of alcohol consumption.

Though dynorphin and KORs are known to be present throughout the BNST (Poulin et al 2009), very little work has been conducted in this region. In 2010, the Kash Lab (Li et al 
2012) demonstrated that activation of KORs produced a robust inhibition of GABA transmission from the CeA, and that this inhibition was presynaptic and MEK/ERK signaling dependent. Despite this promising avenue of investigation, no systematic work has been conducted to further assess KORs in the BNST, either at the pharmacological or behavioral level.

\section{Hippocampus}

KORs play an essential role in HIPP circuitry (Chavkin et al 1985) Dynorphin has been shown to control glutamate transmission in the hippocampus (Wagner et al 1993, Weisskopf et al 1993), as well as increase cell excitability in dentate gyrus granule cells (McDermott \& Schrader 2011). Dynorphin is released from granule cells in the HIPP, and acts as a retrograde transmitter to inhibit excitatory inputs in the HIPP (Drake et al 1994); for further reading see (Chavkin 2000). In addition, Dynorphin activates an inwardly rectifying potassium channel as well as voltage gated potassium channels (Wimpey \& Chavkin 1991), including functioning to inhibit $\mathrm{M}$ current, a voltage-dependent potassium current, in CA1 neurons (Madamba et al 1999). Administration of the KOR antagonist norBNI directly into the HIPP reversed ethanol-induced changes in glutamate transmission (Kuzmin et al 2013). Bilkei-Gorzo et al. showed that mice lacking dynorphin show increased partner recognition; in addition, when exposed to object or social recognition paradigms, mice showed increased Dynorphin-A immunoreactivity in the hippocampus, central amygdala, and basolateral amygdala (Bilkei-Gorzo et al 2014). They have also demonstrated that mice lacking dynorphin show enhanced fear conditioning, known to involve the hippocampus (BilkeiGorzo et al 2012) (however note differences between the effects seen by the Carlezon group with systemic administration of norBNI, discussed above). This work seems to indicate a potential protective effect of KORs in the HIPP. In addition, stress causes both KOR and p38 activation in a variety of brain regions, including the hippocampus, and this was not seen in KOR-/- mice (Bruchas et al 2007). Similar experiments have shown that a single immobilization stress results in increased Dynorphin-A immunoreactivity in the hippocampus as well as the nucleus accumbens (Shirayama et al 2004). Shiryama et al. also demonstrated that infusion of the KOR antagonist norBNI directly into CA3 produced antidepressant effects. Recently, investigators have begun to elucidate some of the mechanism of KOR induced alterations in the HIPP. Previous work demonstrated that dynorphin was upregulated in the HIPP following inhibition of NMDA receptors, in a pCREB-dependent manner (Rittase et al 2014), and others have shown that dynorphin inhibition of NMDA receptors appears to be $\mathrm{pH}$ dependent (Kanemitsu et al 2003). Interestingly, KORs and dynorphin in the HIPP have also been heavily investigated for their potential role in epilepsy (Clynen et al 2014, Dobolyi et al 2014). Dynorphin levels are elevated in the HIPP following a kainic acid induced seizure in rats (Rocha \& Maidment 2003). proDynorphin knockout mice show decreased seizure threshold and faster seizure onset (Loacker et al 2007). Administration of a KOR agonist prevents drug-induced seizures in mice, possibly indicating the presence of a regulatory dynorphin ton in the HIPP (Solbrig et al 2006). In the clinical population, prodynorphin transcription is upregulated in patients with temporal lobe epilepsy (Pirker et al 2009). In line with this information, researchers have speculated that KOR activation may be a potential treatment for seizures, treating abhorrent dynorphin release/KOR activation in the hippocampus (Bortolato \& Solbrig 
2007). This exciting line of hippocampal KOR research provides a promising therapeutic outcome for KOR drugs.

\section{Interactions with other signaling molecules}

\section{Corticotrophin-releasing factor}

It is difficult to discuss the role of KORs in brain functioning without discussing its interactions with the closely related peptide corticotropin-releasing factor (CRF). The interactions between the KOR and CRF systems have been investigated heavily (Koob 2013, Land et al 2008, Tejeda et al 2010). The KOR and CRF systems have long been thought to interact in order to orchestrate anxiety-like responses. Like Dynorphin, CRF is a neuropeptide released in response to stress (Koob 1999). Dynorphin and CRF are coexpressed in the periventricular nucleus of the hypothalamus (Roth et al 1983) as well as the hypothalamic supraoptic nucleus (Meister et al 1990). Axon terminals in the locus coeruleus coexpress dynorphin and CRF, most likely arising for the Dynorphin-CRF co-expressing neurons in the central amygdala (Reyes et al 2008). In addition to this anataomical overlay between the two peptidergic systems, behavioral experiments have hinted at their interactions as well. For example, the KOR antagonist JDTic attenuates CRF-mediated performance errors in a five choice serial reaction time task (Van't Veer et al 2012).

Though much of the literature on stress-related effects focuses on the CRF-1R, an emerging importance has been shown for CRF-2R as well (Gysling 2012), indicating the two receptors may have differing interactions with the KOR system (CRF-1R and CRF-2R are commonly thought to mediate opposing responses, possibly through different locations in the synapse, see (Fu \& Neugebauer 2008)). In the basolateral amygdala, CRF-1 mediated anxiety-like behaviors are dependent on the KOR system (Bruchas et al 2009). Importantly, CRF-1R antagonists can block KOR-dependent reinstatement of cocaine seeking (Valdez et al 2007), and antalarmin, a CRF-1R antagonist, blocked KOR-agonist induced reinstatement of alcohol seeking (Funk et al 2014), highlighting not only how KOR-CRF systems interact in relation to stress and anxiety, but addiction as well. Other work has highlighted the importance of the CRF-2R. Activation of CRF receptors in the CeA increased dynorphin levels as measured by microdialysis; acute alcohol administration also increased dynorphin levels, but this was blocked by a CRF-2R antagonist (a CRF-1R antagonist had no effect) (Lam \& Gianoulakis 2011). In addition, injection of CRF produces a KOR-dependent place aversion, which was blocked by a CRF-2 antagonist but not a CRF-1R antagonist (Land et al 2008). Supporting this, CRF-1R -/- mice still show KOR-dependent place aversion (Contarino \& Papaleo 2005), although this study did not assess CRF-2R -/- mice.

Taken together, CRF-1Rs may interact with KORs to mediate anxiety (and anxiety related to drug withdrawal and relapse), while CRF-2Rs may interact with KORs in a more nuanced manner, possibly related to aversion. This potential interaction between CRF and KOR systems provides further information for the development of therapeutic targets for stress and addiction related disorders, as the two peptidergic systems can be targeted simultaneously. Further work is necessary to elucidate the causal nature of the KOR-CRF systems (for example, KOR activation may induce CRF release, see (Valdez et al 2007)), to

Prog Neuropsychopharmacol Biol Psychiatry. Author manuscript; available in PMC 2016 October 01. 
better understand their relationship (KOR-CRF, CRF-KOR, or bidirectional, and the importance of CRF-1Rs versus CRF-2Rs).

\section{Glucocorticoids}

A smaller literature has emerged looking at interactions between glucocorticoids and KORs. In non-rodent models, KOR agonists have been shown to bind to glucocorticoid receptors (Evans et al 2000), and KORs are known to interaction with the hypothalamic pituitary adrenocortical (HPA) axis (Iyengar et al 1986, Iyengar et al 1987). Prodynorphin mRNA in the hippocampus was decreased in adrenalectomized (ADX) mice, and the effect was rescued with dexamethasone (Thai et al 1992); similar results were seen with aldosterone (Watanabe et al 1995). This initial work points towards the interaction between glucocorticoids and the KOR dynorphin system, although much work is left to be done (particularly, studies should address this relationship outside of the hippocampus, in other regions related to the HPA axis, such as the extended amygdala)

\section{Conclusion: Role of KORs in stress and anxiety, potential as a novel therapeutic target}

Despite the implication that KORs are involved in a wide range of psychiatric conditions, ranging from maladaptive disorders such as addiction and anxiety, to basal states such as social interaction and learning and memory, their use as therapeutics in the clinic has thus far been limited.

In addition, though classic behavioral pharmacology literature has focused on the aversive or the anxiogenic properties of KOR agonists, the invention of novel and advanced techniques to probe the site-specific and molecular interactions with KORs may soon add much needed nuance this global statement. Importantly, we hypothesize that is unlikely that KORs in any single region work in isolation to modulate any given condition, such as anxiety. More likely, is that KORs throughout the brain function to modulate interactions between key brain regions involved in anxiogenic phenotypes (such as the interactions between the PFC, HIPP, and NAC). This point is further supported by differences seen in experiments using global dynorphin KOs and systemic administration of the KOR antagonist norBNI: the dynorphin KOR system may function in discrete brain regions to regulate the anxiogenicanxiolytic spectrum of behaviors by keeping behavioral responses in an optimal range; neither global deletion nor global blockade of components of the KOR system will function properly to modulate behavior. As KORs modulate many of the major circuits involved in psychiatric behaviors (Figure 1), they may be functioning to dampen or enhance communication between key circuits involved in anxiety, as opposed to just taking offline a single nucleus. As further work probes these questions, it may emerge that dynorphins and KORs, in some cases, serve anxiolytic purposes depending on the functional status of the circuit

While KOR antagonists have been at the forefront of treatment options for psychiatric illnesses, they are also implicated in a medley of other physiological disorders, including salt consumption (Nascimento et al 2012), epilepsy and hypertension (though hypertension is

Prog Neuropsychopharmacol Biol Psychiatry. Author manuscript; available in PMC 2016 October 01. 
not discussed here, see(Wright \& Ingenito 2001, Wright \& Ingenito 2003, Wright et al 2000) for further reading). This brings together the importance of the "whole body" perspective when considering KOR drugs as therapeutic treatment for brain-related diseases.

\section{References}

Al-Hasani R, McCall JG, Bruchas MR. Exposure to chronic mild stress prevents kappa opioidmediated reinstatement of cocaine and nicotine place preference. Frontiers in pharmacology. 2013; 4:96. [PubMed: 23964239]

Asensio VJ, Miralles A, Garcia-Sevilla JA. Stimulation of mitogen-activated protein kinase kinases (MEK1/2) by mu-, delta- and kappa-opioid receptor agonists in the rat brain: regulation by chronic morphine and opioid withdrawal. European journal of pharmacology. 2006; 539:49-56. [PubMed: 16678156]

Bals-Kubik R, Ableitner A, Herz A, Shippenberg TS. Neuroanatomical sites mediating the motivational effects of opioids as mapped by the conditioned place preference paradigm in rats. The Journal of pharmacology and experimental therapeutics. 1993; 264:489-95. [PubMed: 8093731]

Beardsley PM, Howard JL, Shelton KL, Carroll FI. Differential effects of the novel kappa opioid receptor antagonist, JDTic, on reinstatement of cocaine-seeking induced by footshock stressors vs cocaine primes and its antidepressant-like effects in rats. Psychopharmacology. 2005; 183:118-26. [PubMed: 16184376]

Belcheva MM, Clark AL, Haas PD, Serna JS, Hahn JW, et al. Mu and kappa opioid receptors activate ERK/MAPK via different protein kinase $\mathrm{C}$ isoforms and secondary messengers in astrocytes. The Journal of biological chemistry. 2005; 280:27662-9. [PubMed: 15944153]

Berger AL, Williams AM, McGinnis MM, Walker BM. Affective cue-induced escalation of alcohol self-administration and increased 22-kHz ultrasonic vocalizations during alcohol withdrawal: role of kappa-opioid receptors. Neuropsychopharmacology : official publication of the American College of Neuropsychopharmacology. 2013; 38:647-54. [PubMed: 23212453]

Berube P, Laforest S, Bhatnagar S, Drolet G. Enkephalin and dynorphin mRNA expression are associated with resilience or vulnerability to chronic social defeat stress. Physiology \& behavior. 2013; 122:237-45. [PubMed: 23665402]

Bidlack, JM. Advances in pharmacology. Vol. 69. San Diego, Calif.: 2014. Mixed kappa/mu partial opioid agonists as potential treatments for cocaine dependence; p. 387-418.

Bilkei-Gorzo A, Erk S, Schurmann B, Mauer D, Michel K, et al. Dynorphins regulate fear memory: from mice to men. The Journal of neuroscience : the official journal of the Society for Neuroscience. 2012; 32:9335-43. [PubMed: 22764240]

Bilkei-Gorzo A, Mauer D, Michel K, Zimmer A. Dynorphins regulate the strength of social memory. Neuropharmacology. 2014; 77:406-13. [PubMed: 24184385]

Bilkei-Gorzo A, Racz I, Michel K, Mauer D, Zimmer A, et al. Control of hormonal stress reactivity by the endogenous opioid system. Psychoneuroendocrinology. 2008; 33:425-36. [PubMed: 18280051]

Bortolato M, Solbrig MV. The price of seizure control: dynorphins in interictal and postictal psychosis. Psychiatry research. 2007; 151:139-43. [PubMed: 17395273]

Braida D, Capurro V, Zani A, Rubino T, Vigano D, et al. Potential anxiolytic- and antidepressant-like effects of salvinorin A, the main active ingredient of Salvia divinorum, in rodents. British journal of pharmacology. 2009; 157:844-53. [PubMed: 19422370]

Braida D, Limonta V, Capurro V, Fadda P, Rubino T, et al. Involvement of kappa-opioid and endocannabinoid system on Salvinorin A-induced reward. Biological psychiatry. 2008; 63:286-92. [PubMed: 17920565]

Bruchas M, Chavkin C. Kinase cascades and ligand-directed signaling at the kappa opioid receptor. Psychopharmacology. 2010a; 210:137-47. [PubMed: 20401607]

Bruchas MR, Chavkin C. Kinase cascades and ligand-directed signaling at the kappa opioid receptor. Psychopharmacology. 2010b; 210:137-47. [PubMed: 20401607] 
Bruchas MR, Land BB, Aita M, Xu M, Barot SK, et al. Stress-induced p38 mitogen-activated protein kinase activation mediates kappa-opioid-dependent dysphoria. The Journal of neuroscience : the official journal of the Society for Neuroscience. 2007; 27:11614-23. [PubMed: 17959804]

Bruchas MR, Land BB, Chavkin C. The dynorphin/kappa opioid system as a modulator of stressinduced and pro-addictive behaviors. Brain research. 2010; 1314:44-55. [PubMed: 19716811]

Bruchas MR, Land BB, Lemos JC, Chavkin C. CRF1-R activation of the dynorphin/kappa opioid system in the mouse basolateral amygdala mediates anxiety-like behavior. PloS one. 2009; 4:e8528. [PubMed: 20052275]

Bruchas MR, Macey TA, Lowe JD, Chavkin C. Kappa opioid receptor activation of p38 MAPK is GRK3- and arrestin-dependent in neurons and astrocytes. The Journal of biological chemistry. 2006; 281:18081-9. [PubMed: 16648139]

Bruchas MR, Schindler AG, Shankar H, Messinger DI, Miyatake M, et al. Selective p38alpha MAPK deletion in serotonergic neurons produces stress resilience in models of depression and addiction. Neuron. 2011; 71:498-511. [PubMed: 21835346]

Bruchas MR, Xu M, Chavkin C. Repeated swim stress induces kappa opioid-mediated activation of extracellular signal-regulated kinase 1/2. Neuroreport. 2008; 19:1417-22. [PubMed: 18766023]

Carr GV, Bangasser DA, Bethea T, Young M, Valentino RJ, Lucki I. Antidepressant-Like Effects of [kappa]-Opioid Receptor Antagonists in Wistar Kyoto Rats. Neuropsychopharmacology : official publication of the American College of Neuropsychopharmacology. 2009; 35:752-63. [PubMed: 19924112]

Carr GV, Bangasser DA, Bethea T, Young M, Valentino RJ, Lucki I. Antidepressant-like effects of kappa-opioid receptor antagonists in Wistar Kyoto rats. Neuropsychopharmacology : official publication of the American College of Neuropsychopharmacology. 2010; 35:752-63. [PubMed: 19924112]

Cashman JR, Azar MR. Potent inhibition of alcohol self-administration in alcohol-preferring rats by a kappa-opioid receptor antagonist. The Journal of pharmacology and experimental therapeutics. 2014; 350:171-80. [PubMed: 24817033]

Castagné, V.; Moser, P.; Roux, S.; Porsolt, RD. Current Protocols in Neuroscience. John Wiley \& Sons, Inc; 2001. Rodent Models of Depression: Forced Swim and Tail Suspension Behavioral Despair Tests in Rats and Mice.

Castro DC, Berridge KC. Opioid hedonic hotspot in nucleus accumbens shell: mu, delta, and kappa maps for enhancement of sweetness "liking" and "wanting". The Journal of neuroscience : the official journal of the Society for Neuroscience. 2014; 34:4239-50. [PubMed: 24647944]

Chartoff E, Sawyer A, Rachlin A, Potter D, Pliakas A, Carlezon WA. Blockade of kappa opioid receptors attenuates the development of depressive-like behaviors induced by cocaine withdrawal in rats. Neuropharmacology. 2012; 62:167-76. [PubMed: 21736885]

Chartoff EH, Papadopoulou M, MacDonald ML, Parsegian A, Potter D, et al. Desipramine reduces stress-activated dynorphin expression and CREB phosphorylation in NAc tissue. Molecular pharmacology. 2009; 75:704-12. [PubMed: 19106229]

Chavkin C. Dynorphins are endogenous opioid peptides released from granule cells to act neurohumorly and inhibit excitatory neurotransmission in the hippocampus. Progress in brain research. 2000; 125:363-7. [PubMed: 11098672]

Chavkin C, Goldstein A. Demonstration of a specific dynorphin receptor in guinea pig ileum myenteric plexus. Nature. 1981a; 291:591-3. [PubMed: 6264311]

Chavkin C, Goldstein A. Specific receptor for the opioid peptide dynorphin: structure--activity relationships. Proceedings of the National Academy of Sciences of the United States of America. 1981b; 78:6543-7. [PubMed: 6118865]

Chavkin, C.; James, IF.; Goldstein, A. Science. Vol. 215. New York, N.Y.: 1982. Dynorphin is a specific endogenous ligand of the kappa opioid receptor; p. 413-5.

Chavkin C, Shoemaker WJ, McGinty JF, Bayon A, Bloom FE. Characterization of the prodynorphin and proenkephalin neuropeptide systems in rat hippocampus. The Journal of neuroscience : the official journal of the Society for Neuroscience. 1985; 5:808-16. [PubMed: 3838345]

Chefer VI, Backman CM, Gigante ED, Shippenberg TS. Kappa opioid receptors on dopaminergic neurons are necessary for kappa-mediated place aversion. Neuropsychopharmacology : official 
publication of the American College of Neuropsychopharmacology. 2013; 38:2623-31. [PubMed: 23921954]

Chefer VI, Czyzyk T, Bolan EA, Moron J, Pintar JE, Shippenberg TS. Endogenous kappa-opioid receptor systems regulate mesoaccumbal dopamine dynamics and vulnerability to cocaine. The Journal of neuroscience : the official journal of the Society for Neuroscience. 2005; 25:5029-37. [PubMed: 15901784]

Chefer VI, Shippenberg TS. Paradoxical effects of prodynorphin gene deletion on basal and cocaineevoked dopaminergic neurotransmission in the nucleus accumbens. The European journal of neuroscience. 2006; 23:229-38. [PubMed: 16420432]

Clynen E, Swijsen A, Raijmakers M, Hoogland G, Rigo JM. Neuropeptides as Targets for the Development of Anticonvulsant Drugs. Molecular neurobiology. 2014

Contarino A, Papaleo F. The corticotropin-releasing factor receptor-1 pathway mediates the negative affective states of opiate withdrawal. Proceedings of the National Academy of Sciences of the United States of America. 2005; 102:18649-54. [PubMed: 16339307]

Cupic B, Stefulj J, Zapletal E, Matosic A, Bordukalo-Niksic T, et al. Opioid system genes in alcoholism: a case-control study in Croatian population. Neuropeptides. 2013; 47:315-9. [PubMed: 24035285]

D'Addario C, Caputi FF, Rimondini R, Gandolfi O, Del Borrello E, et al. Different alcohol exposures induce selective alterations on the expression of dynorphin and nociceptin systems related genes in rat brain. Addiction biology. 2013; 18:425-33. [PubMed: 21507157]

Di Chiara G, Imperato A. Opposite effects of mu and kappa opiate agonists on dopamine release in the nucleus accumbens and in the dorsal caudate of freely moving rats. The Journal of pharmacology and experimental therapeutics. 1988; 244:1067-80. [PubMed: 2855239]

Diaz-Cenzano E, Gaztanaga M, Gabriela Chotro M. Exposure to ethanol on prenatal days 19-20 increases ethanol intake and palatability in the infant rat: involvement of kappa and mu opioid receptors. Developmental psychobiology. 2014; 56:1167-78. [PubMed: 24037591]

Dobolyi A, Kekesi KA, Juhasz G, Szekely AD, Lovas G, Kovacs Z. Receptors of peptides as therapeutic targets in epilepsy research. Current medicinal chemistry. 2014; 21:764-87. [PubMed: 24251562]

Drake CT, Terman GW, Simmons ML, Milner TA, Kunkel DD, et al. Dynorphin opioids present in dentate granule cells may function as retrograde inhibitory neurotransmitters. The Journal of neuroscience : the official journal of the Society for Neuroscience. 1994; 14:3736-50. [PubMed: 7911518]

Ehrich JM, Phillips PE. Kappa Opioid Receptor Activation Potentiates the Cocaine-Induced Increase in Evoked Dopamine Release Recorded In Vivo in the Mouse Nucleus Accumbens. Neuropsychopharmacology : official publication of the American College of Neuropsychopharmacology. 2014; 39:3036-48. [PubMed: 24971603]

Endoh T, Matsuura H, Tanaka C, Nagase H. Nor-binaltorphimine: a potent and selective kappa-opioid receptor antagonist with long-lasting activity in vivo. Archives internationales de pharmacodynamie et de therapie. 1992; 316:30-42. [PubMed: 1326932]

Evans SJ, Searcy BT, Moore FL. A subset of kappa opioid ligands bind to the membrane glucocorticoid receptor in an amphibian brain. Endocrinology. 2000; 141:2294-300. [PubMed: 10875228]

Faisal M, Waseem D, Ismatullah H, Taqi MM. A molecular prospective provides new insights into implication of PDYN and OPRK1 genes in alcohol dependence. Computers in biology and medicine. 2014; 53c:250-57. [PubMed: 25177835]

Freeman KB, Naylor JE, Prisinzano TE, Woolverton WL. Assessment of the kappa opioid agonist, salvinorin A, as a punisher of drug self-administration in monkeys. Psychopharmacology (Berl). 2014; 231:2751-8. [PubMed: 24481567]

Fu Y, Neugebauer V. Differential mechanisms of CRF1 and CRF2 receptor functions in the amygdala in pain-related synaptic facilitation and behavior. The Journal of neuroscience : the official journal of the Society for Neuroscience. 2008; 28:3861-76. [PubMed: 18400885]

Prog Neuropsychopharmacol Biol Psychiatry. Author manuscript; available in PMC 2016 October 01. 
Funada M, Suzuki T, Narita M, Misawa M, Nagase H. Blockade of morphine reward through the activation of kappa-opioid receptors in mice. Neuropharmacology. 1993; 32:1315-23. [PubMed: 7908722]

Funk D, Coen K, Le AD. The role of kappa opioid receptors in stress-induced reinstatement of alcohol seeking in rats. Brain and behavior. 2014; 4:356-67. [PubMed: 24944865]

Gehrke BJ, Chefer VI, Shippenberg TS. Effects of acute and repeated administration of salvinorin A on dopamine function in the rat dorsal striatum. Psychopharmacology (Berl). 2008; 197:509-17. [PubMed: 18246329]

Gieryk A, Ziolkowska B, Solecki W, Kubik J, Przewlocki R. Forebrain PENK and PDYN gene expression levels in three inbred strains of mice and their relationship to genotype-dependent morphine reward sensitivity. Psychopharmacology (Berl). 2010; 208:291-300. [PubMed: 19997907]

Gilpin NW, Roberto M, Koob GF, Schweitzer P. Kappa opioid receptor activation decreases inhibitory transmission and antagonizes alcohol effects in rat central amygdala. Neuropharmacology. 2014; 77:294-302. [PubMed: 24157490]

Glick SD, Maisonneuve IM, Raucci J, Sydney A. Kappa opioid inhibition of morphine and cocaine self-administration in rats. Brain research. 1995; 681:147-52. [PubMed: 7552272]

Graziane NM, Polter AM, Briand LA, Pierce RC, Kauer JA. Kappa opioid receptors regulate stressinduced cocaine seeking and synaptic plasticity. Neuron. 2013; 77:942-54. [PubMed: 23473323]

Gysling K. Relevance of both type- 1 and type- 2 corticotropin releasing factor receptors in stressinduced relapse to cocaine seeking behaviour. Biochemical pharmacology. 2012; 83:1-5. [PubMed: 21843515]

Hahn JW, Jagwani S, Kim E, Rendell VR, He J, et al. Mu and kappa opioids modulate mouse embryonic stem cell-derived neural progenitor differentiation via MAP kinases. Journal of neurochemistry. 2010; 112:1431-41. [PubMed: 19895666]

Hasebe K, Kawai K, Suzuki T, Kawamura K, Tanaka T, et al. Possible pharmacotherapy of the opioid kappa receptor agonist for drug dependence. Annals of the New York Academy of Sciences. 2004; 1025:404-13. [PubMed: 15542743]

Heilig M, Schank JR. Kappa-opioid receptor antagonism: a mechanism for treatment of relief drinking? Biological psychiatry. 2014; 75:750-1. [PubMed: 24780009]

Henderson-Redmond A, Czachowski C. Effects of systemic opioid receptor ligands on ethanol- and sucrose seeking and drinking in alcohol-preferring $(\mathrm{P})$ and Long Evans rats. Psychopharmacology. 2014; 231:4309-21. [PubMed: 24770627]

Hjelmstad GO, Fields HL. Kappa opioid receptor activation in the nucleus accumbens inhibits glutamate and GABA release through different mechanisms. Journal of neurophysiology. 2003; 89:2389-95. [PubMed: 12740400]

Hospital MG. Proof-of-Concept Trial of LY2456302 Augmentation of Antidepressant Therapy in Treatment-Resistant Depression. Jul 30.2013

Huge, V.; Rammes, G.; Beyer, A.; Zieglgansberger, W.; Azad, SC. European journal of pain. Vol. 13. London, England: 2009. Activation of kappa opioid receptors decreases synaptic transmission and inhibits long-term potentiation in the basolateral amygdale of the mouse; p. 124-9.

Iyengar S, Kim HS, Wood PL. Kappa opiate agonists modulate the hypothalamic-pituitaryadrenocortical axis in the rat. The Journal of pharmacology and experimental therapeutics. 1986; 238:429-36. [PubMed: 3016237]

Iyengar S, Kim HS, Wood PL. $\mu-, \delta-, \kappa$ - and $\varepsilon$-Opioid receptor modulation of the hypothalamicpituitary-adrenocortical (HPA) axis: subchronic tolerance studies of endogenous opioid peptides. Brain research. 1987; 435:220-26. [PubMed: 2892574]

Kallupi M, Wee S, Edwards S, Whitfield TW Jr, Oleata CS, et al. Kappa opioid receptor-mediated dysregulation of gamma-aminobutyric acidergic transmission in the central amygdala in cocaine addiction. Biological psychiatry. 2013; 74:520-8. [PubMed: 23751206]

Kanemitsu Y, Hosoi M, Zhu PJ, Weight FF, Peoples RW, et al. Dynorphin A inhibits NMDA receptors through a $\mathrm{pH}$-dependent mechanism. Molecular and cellular neurosciences. 2003; 24:525-37. [PubMed: 14664805]

Prog Neuropsychopharmacol Biol Psychiatry. Author manuscript; available in PMC 2016 October 01. 
Kang-Park M, Kieffer BL, Roberts AJ, Siggins GR, Moore SD. kappa-Opioid receptors in the central amygdala regulate ethanol actions at presynaptic GABAergic sites. The Journal of pharmacology and experimental therapeutics. 2013; 346:130-7. [PubMed: 23587526]

Kaster MP, Budni J, Santos AR, Rodrigues AL. Pharmacological evidence for the involvement of the opioid system in the antidepressant-like effect of adenosine in the mouse forced swimming test. European journal of pharmacology. 2007; 576:91-8. [PubMed: 17868670]

Kissler JL, Sirohi S, Reis DJ, Jansen HT, Quock RM, et al. The one-two punch of alcoholism: role of central amygdala dynorphins/kappa-opioid receptors. Biological psychiatry. 2014; 75:774-82. [PubMed: 23611261]

Kivell B, Uzelac Z, Sundaramurthy S, Rajamanickam J, Ewald A, et al. Salvinorin A regulates dopamine transporter function via a kappa opioid receptor and ERK1/2-dependent mechanism. Neuropharmacology. 2014a; 86c:228-40. [PubMed: 25107591]

Kivell B, Uzelac Z, Sundaramurthy S, Rajamanickam J, Ewald A, et al. Salvinorin A regulates dopamine transporter function via a kappa opioid receptor and ERK1/2-dependent mechanism. Neuropharmacology. 2014b; 86:228-40. [PubMed: 25107591]

Knoll AT, Meloni EG, Thomas JB, Carroll FI, Carlezon WA Jr. Anxiolytic-like effects of kappaopioid receptor antagonists in models of unlearned and learned fear in rats. The Journal of pharmacology and experimental therapeutics. 2007; 323:838-45. [PubMed: 17823306]

Knoll AT, Muschamp JW, Sillivan SE, Ferguson D, Dietz DM, et al. Kappa opioid receptor signaling in the basolateral amygdala regulates conditioned fear and anxiety in rats. Biological psychiatry. 2011; 70:425-33. [PubMed: 21531393]

Koob GF. Stress, corticotropin-releasing factor, and drug addiction. Annals of the New York Academy of Sciences. 1999; 897:27-45. [PubMed: 10676433]

Koob GF. Addiction is a Reward Deficit and Stress Surfeit Disorder. Frontiers in psychiatry. 2013; 4:72. [PubMed: 23914176]

Kovacs KM, Szakall I, O'Brien D, Wang R, Vinod KY, et al. Decreased oral self-administration of alcohol in kappa-opioid receptor knock-out mice. Alcoholism, clinical and experimental research. 2005; 29:730-8.

Kuzmin A, Chefer V, Bazov I, Meis J, Ogren SO, et al. Upregulated dynorphin opioid peptides mediate alcohol-induced learning and memory impairment. Translational psychiatry. 2013; 3:e310. [PubMed: 24105441]

Lam, MP.; Gianoulakis, C. Alcohol. Vol. 45. Fayetteville, N.Y.: 2011. Effects of corticotropinreleasing hormone receptor antagonists on the ethanol-induced increase of dynorphin A1-8 release in the rat central amygdala; p. 621-30.

Land BB, Bruchas MR, Lemos JC, Xu M, Melief EJ, Chavkin C. The dysphoric component of stress is encoded by activation of the dynorphin kappa-opioid system. The Journal of neuroscience : the official journal of the Society for Neuroscience. 2008; 28:407-14. [PubMed: 18184783]

Land BB, Bruchas MR, Schattauer S, Giardino WJ, Aita M, et al. Activation of the kappa opioid receptor in the dorsal raphe nucleus mediates the aversive effects of stress and reinstates drug seeking. Proceedings of the National Academy of Sciences. 2009; 106:19168-73.

Le A, Shaham Y. Neurobiology of relapse to alcohol in rats. Pharmacology \& therapeutics. 2002; 94:137-56. [PubMed: 12191599]

Leeman RF, Heilig M, Cunningham CL, Stephens DN, Duka T, O'Malley SS. Ethanol consumption: how should we measure it? Achieving consilience between human and animal phenotypes. Addiction biology. 2010; 15:109-24. [PubMed: 20148775]

Lemos JC, Roth CA, Messinger DI, Gill HK, Phillips PE, Chavkin C. Repeated stress dysregulates kappa-opioid receptor signaling in the dorsal raphe through a p38alpha MAPK-dependent mechanism. The Journal of neuroscience : the official journal of the Society for Neuroscience. 2012; 32:12325-36. [PubMed: 22956823]

Li C, Pleil KE, Stamatakis AM, Busan S, Vong L, et al. Presynaptic inhibition of gamma-aminobutyric acid release in the bed nucleus of the stria terminalis by kappa opioid receptor signaling. Biological psychiatry. 2012; 71:725-32. [PubMed: 22225848]

Li JG, Luo LY, Krupnick JG, Benovic JL, Liu-Chen LY. U50,488H-induced Internalization of the Human $\kappa$ Opioid Receptor Involves a $\beta$-Arrestin- and Dynamin-dependent Mechanism: $\kappa$ Receptor

Prog Neuropsychopharmacol Biol Psychiatry. Author manuscript; available in PMC 2016 October 01. 
Internalization is not Required for Mitogen-Activated Protein Kinase Activation. Journal of Biological Chemistry. 1999; 274:12087-94. [PubMed: 10207034]

Li Z, Zhang H. Analyzing Interaction of mu-, delta- and kappa-opioid Receptor Gene Variants on Alcohol or Drug Dependence Using a Pattern Discovery-based Method. Journal of addiction research \& therapy Suppl. 2013; 7:007.

Loacker S, Sayyah M, Wittmann W, Herzog H, Schwarzer C. Endogenous dynorphin in epileptogenesis and epilepsy: anticonvulsant net effect via kappa opioid receptors. Brain : a journal of neurology. 2007; 130:1017-28. [PubMed: 17347252]

Lowe SL, Wong CJ, Witcher J, Gonzales CR, Dickinson GL, et al. Safety, tolerability, and pharmacokinetic evaluation of single- and multiple-ascending doses of a novel kappa opioid receptor antagonist LY2456302 and drug interaction with ethanol in healthy subjects. Journal of clinical pharmacology. 2014; 54:968-78. [PubMed: 24619932]

Lowery-Gionta EG, Marcinkiewcz CA, Kash TL. Functional Alterations in the Dorsal Raphe Nucleus Following Acute and Chronic Ethanol Exposure. Neuropsychopharmacology : official publication of the American College of Neuropsychopharmacology. 2014

Lucas LR, Dragisic T, Duwaerts CC, Swiatkowski M, Suzuki H. Effects of recovery from immobilization stress on striatal preprodynorphin- and kappa opioid receptor-mRNA levels of the male rat. Physiology \& behavior. 2011; 104:972-80. [PubMed: 21723305]

Madamba SG, Schweitzer P, Siggins GR. Dynorphin selectively augments the M-current in hippocampal CA1 neurons by an opiate receptor mechanism. Journal of neurophysiology. 1999; 82:1768-75. [PubMed: 10515966]

Mague SD, Pliakas AM, Todtenkopf MS, Tomasiewicz HC, Zhang Y, et al. Antidepressant-like effects of kappa-opioid receptor antagonists in the forced swim test in rats. The Journal of pharmacology and experimental therapeutics. 2003; 305:323-30. [PubMed: 12649385]

Maier SF, Watkins LR. Stressor controllability and learned helplessness: the roles of the dorsal raphe nucleus, serotonin, and corticotropin-releasing factor. Neuroscience and biobehavioral reviews. 2005; 29:829-41. [PubMed: 15893820]

Manzoni OJ, Williams JT. Presynaptic regulation of glutamate release in the ventral tegmental area during morphine withdrawal. The Journal of neuroscience : the official journal of the Society for Neuroscience. 1999; 19:6629-36. [PubMed: 10414991]

Marchant NJ, Densmore VS, Osborne PB. Coexpression of prodynorphin and corticotrophin-releasing hormone in the rat central amygdala: evidence of two distinct endogenous opioid systems in the lateral division. The Journal of comparative neurology. 2007; 504:702-15. [PubMed: 17722034]

Margolis EB, Hjelmstad GO, Bonci A, Fields HL. Kappa-opioid agonists directly inhibit midbrain dopaminergic neurons. The Journal of neuroscience : the official journal of the Society for Neuroscience. 2003; 23:9981-6. [PubMed: 14602811]

Margolis EB, Hjelmstad GO, Bonci A, Fields HL. Both kappa and mu opioid agonists inhibit glutamatergic input to ventral tegmental area neurons. Journal of neurophysiology. 2005; 93:3086-93. [PubMed: 15615834]

Margolis EB, Lock H, Chefer VI, Shippenberg TS, Hjelmstad GO, Fields HL. Kappa opioids selectively control dopaminergic neurons projecting to the prefrontal cortex. Proceedings of the National Academy of Sciences of the United States of America. 2006; 103:2938-42. [PubMed: 16477003]

Margolis EB, Mitchell JM, Ishikawa J, Hjelmstad GO, Fields HL. Midbrain dopamine neurons: projection target determines action potential duration and dopamine $\mathrm{D}(2)$ receptor inhibition. The Journal of neuroscience : the official journal of the Society for Neuroscience. 2008; 28:8908-13. [PubMed: 18768684]

McDermott CM, Schrader LA. Activation of kappa opioid receptors increases intrinsic excitability of dentate gyrus granule cells. The Journal of physiology. 2011; 589:3517-32. [PubMed: 21606111]

McLaughlin JP, Land BB, Li S, Pintar JE, Chavkin C. Prior activation of kappa opioid receptors by U50, 488 mimics repeated forced swim stress to potentiate cocaine place preference conditioning. Neuropsychopharmacology : official publication of the American College of Neuropsychopharmacology. 2006; 31:787-94. [PubMed: 16123754]

Prog Neuropsychopharmacol Biol Psychiatry. Author manuscript; available in PMC 2016 October 01. 
McLaughlin JP, Marton-Popovici M, Chavkin C. Kappa opioid receptor antagonism and prodynorphin gene disruption block stress-induced behavioral responses. The Journal of neuroscience : the official journal of the Society for Neuroscience. 2003; 23:5674-83. [PubMed: 12843270]

McLennan GP, Kiss A, Miyatake M, Belcheva MM, Chambers KT, et al. Kappa opioids promote the proliferation of astrocytes via Gbetagamma and beta-arrestin 2-dependent MAPK-mediated pathways. Journal of neurochemistry. 2008; 107:1753-65. [PubMed: 19014370]

Meister B, Villar MJ, Ceccatelli S, Hokfelt T. Localization of chemical messengers in magnocellular neurons of the hypothalamic supraoptic and paraventricular nuclei: an immunohistochemical study using experimental manipulations. Neuroscience. 1990; 37:603-33. [PubMed: 1701038]

Morales M, Anderson RI, Spear LP, Varlinskaya EI. Effects of the kappa opioid receptor antagonist, nor-binaltorphimine, on ethanol intake: impact of age and sex. Developmental psychobiology. 2014; 56:700-12. [PubMed: 23754134]

Mu P, Neumann PA, Panksepp J, Schluter OM, Dong Y. Exposure to cocaine alters dynorphinmediated regulation of excitatory synaptic transmission in nucleus accumbens neurons. Biological psychiatry. 2011; 69:228-35. [PubMed: 21030009]

Muschamp JW, Hollander JA, Thompson JL, Voren G, Hassinger LC, et al. Hypocretin (orexin) facilitates reward by attenuating the antireward effects of its cotransmitter dynorphin in ventral tegmental area. Proceedings of the National Academy of Sciences of the United States of America. 2014; 111:E1648-55. [PubMed: 24706819]

Nascimento AI, Ferreira HS, Saraiva RM, Almeida TS, Fregoneze JB. Central kappa opioid receptors modulate salt appetite in rats. Physiology \& behavior. 2012; 106:506-14. [PubMed: 22484111]

Nizhnikov ME, Pautassi RM, Carter JM, Landin JD, Varlinskaya EI, et al. Brief prenatal ethanol exposure alters behavioral sensitivity to the kappa opioid receptor agonist (U62,066E) and antagonist (Nor-BNI) and reduces kappa opioid receptor expression. Alcoholism, clinical and experimental research. 2014; 38:1630-8.

Nutt, DJ. Journal of psychopharmacology. Vol. 28. Oxford, England: 2014. The role of the opioid system in alcohol dependence; p. 8-22.

Pellow S, File SE. Anxiolytic and anxiogenic drug effects on exploratory activity in an elevated plusmaze: a novel test of anxiety in the rat. Pharmacology, biochemistry, and behavior. 1986; 24:525-9.

Peters MF, Zacco A, Gordon J, Maciag CM, Litwin LC, et al. Identification of short-acting kappaopioid receptor antagonists with anxiolytic-like activity. European journal of pharmacology. 2011; 661:27-34. [PubMed: 21539838]

Pfeiffer, A.; Brantl, V.; Herz, A.; Emrich, HM. Science. Vol. 233. New York, N.Y.: 1986. Psychotomimesis mediated by kappa opiate receptors; p. 774-6.

Pinnock RD. Activation of kappa-opioid receptors depresses electrically evoked excitatory postsynaptic potentials on 5-HT-sensitive neurones in the rat dorsal raphe nucleus in vitro. Brain research. 1992; 583:237-46. [PubMed: 1354563]

Pirker S, Gasser E, Czech T, Baumgartner C, Schuh E, et al. Dynamic up-regulation of prodynorphin transcription in temporal lobe epilepsy. Hippocampus. 2009; 19:1051-4. [PubMed: 19437412]

Porsolt RD, Le Pichon M, Jalfre M. Depression: a new animal model sensitive to antidepressant treatments. Nature. 1977; 266:730-32. [PubMed: 559941]

Potter DN, Damez-Werno D, Carlezon WA Jr, Cohen BM, Chartoff EH. Repeated exposure to the kappa-opioid receptor agonist salvinorin A modulates extracellular signal-regulated kinase and reward sensitivity. Biological psychiatry. 2011; 70:744-53. [PubMed: 21757186]

Poulin JF, Arbour D, Laforest S, Drolet G. Neuroanatomical characterization of endogenous opioids in the bed nucleus of the stria terminalis. Progress in neuro-psychopharmacology \& biological psychiatry. 2009; 33:1356-65. [PubMed: 19583989]

Privette TH, Terrian DM. Kappa opioid agonists produce anxiolytic-like behavior on the elevated plusmaze. Psychopharmacology (Berl). 1995; 118:444-50. [PubMed: 7568631]

Racz I, Markert A, Mauer D, Stoffel-Wagner B, Zimmer A. Long-term ethanol effects on acute stress responses: modulation by dynorphin. Addiction biology. 2013; 18:678-88. [PubMed: 22994904]

Prog Neuropsychopharmacol Biol Psychiatry. Author manuscript; available in PMC 2016 October 01. 
Reindl JD, Rowan K, Carey AN, Peng X, Neumeyer JL, McLaughlin JP. Antidepressant-like effects of the novel kappa opioid antagonist MCL-144B in the forced-swim test. Pharmacology. 2008; 81:229-35. [PubMed: 18176093]

Reyes BA, Drolet G, Van Bockstaele EJ. Dynorphin and stress-related peptides in rat locus coeruleus: contribution of amygdalar efferents. The Journal of comparative neurology. 2008; 508:663-75. [PubMed: 18381633]

Rittase WB, Dong Y, Barksdale D, Galdzicki Z, Bausch SB. Dynorphin up-regulation in the dentate granule cell mossy fiber pathway following chronic inhibition of GluN2B-containing NMDAR is associated with increased CREB (Ser 133) phosphorylation, but is independent of BDNF/TrkB signaling pathways. Molecular and cellular neurosciences. 2014; 60:63-71. [PubMed: 24769103]

Rocha L, Maidment NT. Opioid peptide release in the rat hippocampus after kainic acid-induced status epilepticus. Hippocampus. 2003; 13:472-80. [PubMed: 12836916]

Roth, KA.; Weber, E.; Barchas, JD.; Chang, D.; Chang, JK. Science. Vol. 219. New York, N.Y.: 1983. Immunoreactive dynorphin-(1-8) and corticotropin- releasing factor in subpopulation of hypothalamic neurons; p. 189-91.

RTI-International. First in Humans Study of JDTic. May 9.2012

Schank JR, Goldstein AL, Rowe KE, King CE, Marusich JA, et al. The kappa opioid receptor antagonist JDTic attenuates alcohol seeking and withdrawal anxiety. Addiction biology. 2012; 17:634-47. [PubMed: 22515275]

Schlosburg JE, Whitfield TW Jr, Park PE, Crawford EF, George O, et al. Long-term antagonism of kappa opioid receptors prevents escalation of and increased motivation for heroin intake. The Journal of neuroscience : the official journal of the Society for Neuroscience. 2013; 33:1938492. [PubMed: 24305833]

Sedki F, Eigenmann K, Gelinas J, Schouela N, Courchesne S, Shalev U. A role for kappa-, but not muopioid, receptor activation in acute food deprivation-induced reinstatement of heroin seeking in rats. Addiction biology. 2014:1-10.

Shippenberg TS, Bals-Kubik R, Herz A. Examination of the neurochemical substrates mediating the motivational effects of opioids: role of the mesolimbic dopamine system and D-1 vs. D-2 dopamine receptors. The Journal of pharmacology and experimental therapeutics. 1993; 265:539. [PubMed: 8386244]

Shippenberg TS, LeFevour A, Heidbreder C. kappa-Opioid receptor agonists prevent sensitization to the conditioned rewarding effects of cocaine. The Journal of pharmacology and experimental therapeutics. 1996; 276:545-54. [PubMed: 8632320]

Shirayama Y, Ishida H, Iwata M, Hazama GI, Kawahara R, Duman RS. Stress increases dynorphin immunoreactivity in limbic brain regions and dynorphin antagonism produces antidepressant-like effects. Journal of neurochemistry. 2004; 90:1258-68. [PubMed: 15312181]

Solbrig MV, Adrian R, Baratta J, Lauterborn JC, Koob GF. Kappa opioid control of seizures produced by a virus in an animal model. Brain : a journal of neurology. 2006; 129:642-54. [PubMed: 16399805]

Spanagel R, Almeida OF, Bartl C, Shippenberg TS. Endogenous kappa-opioid systems in opiate withdrawal: role in aversion and accompanying changes in mesolimbic dopamine release. Psychopharmacology (Berl). 1994; 115:121-7. [PubMed: 7862883]

Spanagel R, Herz A, Shippenberg TS. Opposing tonically active endogenous opioid systems modulate the mesolimbic dopaminergic pathway. Proceedings of the National Academy of Sciences of the United States of America. 1992; 89:2046-50. [PubMed: 1347943]

Svingos, AL.; Chavkin, C.; Colago, EE.; Pickel, VM. Synapse. Vol. 42. New York, N.Y.: 2001. Major coexpression of kappa-opioid receptors and the dopamine transporter in nucleus accumbens axonal profiles; p. 185-92.

Svingos AL, Colago EE. Kappa-Opioid and NMDA glutamate receptors are differentially targeted within rat medial prefrontal cortex. Brain research. 2002; 946:262-71. [PubMed: 12137930]

Tao R, Auerbach SB. mu-Opioids disinhibit and kappa-opioids inhibit serotonin efflux in the dorsal raphe nucleus. Brain research. 2005; 1049:70-9. [PubMed: 15935332]

Prog Neuropsychopharmacol Biol Psychiatry. Author manuscript; available in PMC 2016 October 01. 
Tejeda HA, Chefer VI, Zapata A, Shippenberg TS. The effects of kappa-opioid receptor ligands on prepulse inhibition and CRF-induced prepulse inhibition deficits in the rat. Psychopharmacology (Berl). 2010; 210:231-40. [PubMed: 20232058]

Tejeda HA, Counotte DS, Oh E, Ramamoorthy S, Schultz-Kuszak KN, et al. Prefrontal cortical kappaopioid receptor modulation of local neurotransmission and conditioned place aversion. Neuropsychopharmacology : official publication of the American College of Neuropsychopharmacology. 2013; 38:1770-9. [PubMed: 23542927]

Thai L, Lee PH, Ho J, Suh H, Hong JS. Regulation of prodynorphin gene expression in the hippocampus by glucocorticoids. Brain research Molecular brain research. 1992; 16:150-7. [PubMed: 1334193]

Todtenkopf MS, Marcus JF, Portoghese PS, Carlezon WA Jr. Effects of kappa-opioid receptor ligands on intracranial self-stimulation in rats. Psychopharmacology. 2004; 172:463-70. [PubMed: 14727002]

Tomkins, DM.; Sellers, EM.; Fletcher, PJ. Alcohol and alcoholism. Oxford, Oxfordshire: 1994. Effect of dorsal raphe injections of the GABAA agonist, muscimol, on ethanol intake and measures of intoxication in Wistar rats; p. 551-8.

Trifilieff $\mathrm{P}$, Martinez D. Kappa-opioid receptor signaling in the striatum as a potential modulator of dopamine transmission in cocaine dependence. Frontiers in psychiatry. 2013a; 4

Trifilieff P, Martinez D. Kappa-opioid receptor signaling in the striatum as a potential modulator of dopamine transmission in cocaine dependence. Frontiers in psychiatry. 2013b; 4:44. [PubMed: 23760592]

Valdez GR, Harshberger E. kappa opioid regulation of anxiety-like behavior during acute ethanol withdrawal. Pharmacology, biochemistry, and behavior. 2012; 102:44-7.

Valdez GR, Platt DM, Rowlett JK, Ruedi-Bettschen D, Spealman RD. Kappa agonist-induced reinstatement of cocaine seeking in squirrel monkeys: a role for opioid and stress-related mechanisms. The Journal of pharmacology and experimental therapeutics. 2007; 323:525-33. [PubMed: 17702903]

Van't Veer A, Yano JM, Carroll FI, Cohen BM, Carlezon WA Jr. Corticotropin-releasing factor (CRF)-induced disruption of attention in rats is blocked by the kappa-opioid receptor antagonist JDTic. Neuropsychopharmacology : official publication of the American College of Neuropsychopharmacology. 2012; 37:2809-16. [PubMed: 22948977]

Vander Weele CM, Porter-Stransky KA, Mabrouk OS, Lovic V, Singer BF, et al. Rapid dopamine transmission within the nucleus accumbens: Dramatic difference between morphine and oxycodone delivery. The European journal of neuroscience. 2014; 40:3041-54. [PubMed: 25208732]

Wagner JJ, Terman GW, Chavkin C. Endogenous dynorphins inhibit excitatory neurotransmission and block LTP induction in the hippocampus. Nature. 1993; 363:451-4. [PubMed: 8099201]

Walker, BM.; Valdez, GR.; McLaughlin, JP.; Bakalkin, G. Alcohol. Vol. 46. Fayetteville, N.Y.: 2012. Targeting dynorphin/kappa opioid receptor systems to treat alcohol abuse and dependence; $\mathrm{p}$. 359-70.

Wan XW, Li WH, Huang M, You ZD, Tan YX, et al. Levels of immunoreactive dynorphin A1-13 during development of morphine dependence in rats. Zhongguo yao li xue bao = Acta pharmacologica Sinica. 1998; 19:560-3. [PubMed: 10437147]

Wang SC, Tsou HH, Chung RH, Chang YS, Fang CP, et al. The association of genetic polymorphisms in the kappa-opioid receptor 1 gene with body weight, alcohol use, and withdrawal symptoms in patients with methadone maintenance. Journal of clinical psychopharmacology. 2014; 34:20511. [PubMed: 24525640]

Watanabe Y, Weiland NG, McEwen BS. Effects of adrenal steroid manipulations and repeated restraint stress on dynorphin mRNA levels and excitatory amino acid receptor binding in hippocampus. Brain research. 1995; 680:217-25. [PubMed: 7663979]

Wee S, Koob GF. The role of the dynorphin-kappa opioid system in the reinforcing effects of drugs of abuse. Psychopharmacology (Berl). 2010; 210:121-35. [PubMed: 20352414]

Prog Neuropsychopharmacol Biol Psychiatry. Author manuscript; available in PMC 2016 October 01. 
Weisskopf MG, Zalutsky RA, Nicoll RA. The opioid peptide dynorphin mediates heterosynaptic depression of hippocampal mossy fibre synapses and modulates long-term potentiation. Nature. 1993; 362:423-7. [PubMed: 8096624]

Wimpey TL, Chavkin C. Opioids activate both an inward rectifier and a novel voltage-gated potassium conductance in the hippocampal formation. Neuron. 1991; 6:281-9. [PubMed: 1993123]

Wright RC, Ingenito AJ. Prevention of isolation-induced hypertension by intrahippocampal administration of a nonpeptide kappa-opioid receptor agonist. Hippocampus. 2001; 11:445-51. [PubMed: 11530849]

Wright RC, Ingenito AJ. Blockade of dorsal hippocampal kappa-opioid receptors increases blood pressure in normotensive and isolation-induced hypertensive rats. Neuropeptides. 2003; 37:12732. [PubMed: 12747945]

Wright RC, McConnaughey MM, Ingenito AJ. Decreased dynorphin levels and increased kappa opioid receptor binding in male rats with isolation-induced hypertension. Peptides. 2000; 21:1881-4. [PubMed: 11150650]

Yoshizawa, K.; Narita, M.; Saeki, M.; Narita, M.; Isotani, K., et al. Synapse. Vol. 65. New York, N.Y.: 2011. Activation of extracellular signal-regulated kinase is critical for the discriminative stimulus effects induced by U-50,488H; p. 1052-61.

Zheng MQ, Nabulsi N, Kim SJ, Tomasi G, Lin SF, et al. Synthesis and evaluation of 11C-LY2795050 as a kappa-opioid receptor antagonist radiotracer for PET imaging. Journal of nuclear medicine : official publication, Society of Nuclear Medicine. 2013; 54:455-63.

Zhou Y, Colombo G, Gessa GL, Kreek MJ. Effects of voluntary alcohol drinking on corticotropinreleasing factor and preprodynorphin mRNA levels in the central amygdala of Sardinian alcoholpreferring rats. Neuroscience letters. 2013; 554:110-4. [PubMed: 24021806] 


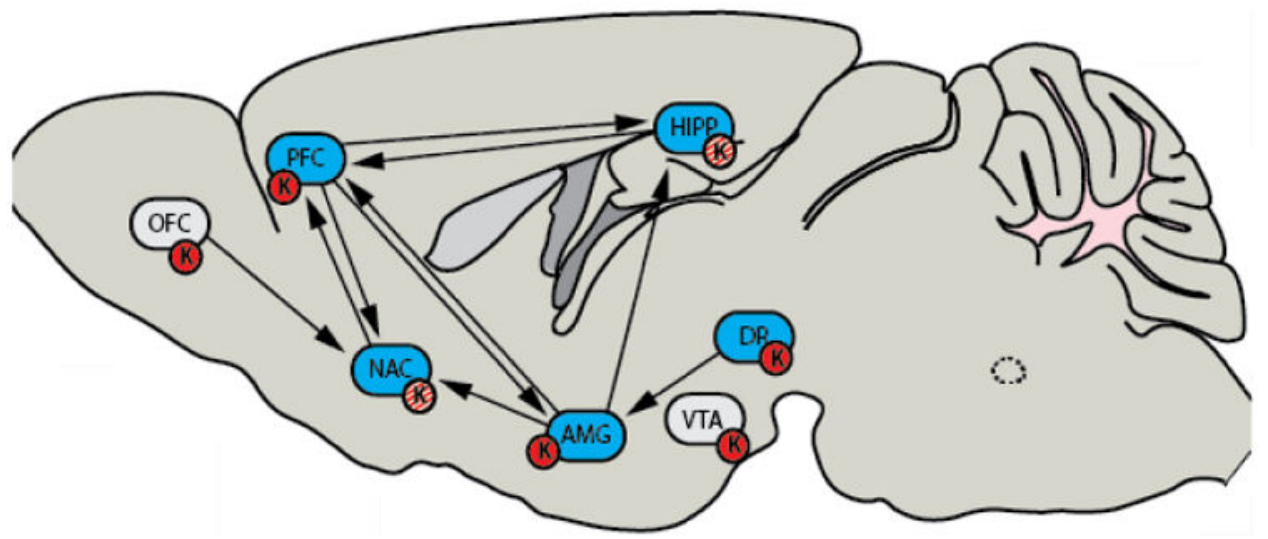

Figure 1. Kappa Opioid Receptors modulate the interactions between major circuits involved in stress responses, anxiety, and addiction

KORs are found in many key brain regions known to be involved in a variety of diseases, such as anxiety and addiction. It has been found that KORs do not only mediate aversive or anxiogenic responses (red circles); literature has shown that KORs (red and white circles) can also be reinforcing, such as in the nucleus accumbens. In addition, dynorphin knockout mice show increased fear conditioning. Key: Orbital frontal cortex (OFC); Pre frontal cortex (PFC); Nucleus accumbens (NAC); Amygdala and extended amygdala (AMG); Hippocampus (HIPP); Ventral Tegmental Area (VTA); Dorsal Raphe Nucleus (DR); Kappa Opioid Receptor (K). 